УДК 17.022.1:140.8

DOI:

Надія Ашиток, доктор філософських наук, професор кафедри соиіальної педагогіки та корекційної освіти Дрогобииького державного педагогічного університету імені Івана Франка

\title{
ДИНАМІЧНІСТЬ ТЕРМІНОЛОГІЇ СПЕЦІАЛЬНОЇ ПЕДАГОГІКИ В ІНФОРМАЦІЙНУ ЕРУ
}

Автор аналізує інформаційні виклики ХХІ століття, щуо впливають на проблеми спеціальної освіти. $У$ статті представлений аналіз термінів "дефектологія", “корекиійна педагогіка" $і$ "інклюзивна педагогіка". Обтрунтовано доиільність використання терміна "інклюзивна освіта” для позначення освіти для всіх дітей, щчо навчаються в інклюзивну закладі.

Ключові слова: інформаційне суспільство; діти з особливими потребами; спеціальна освіта; дефектологія; корекиійна педагогіка; інклюзивна педагогіка.

Jim. 12.

Nadiya Ashytok, Doctor of Sciences (Philosophy), Professor of the Social Pedagogy and Correctional Education Department Drohobych Ivan Franko State Pedagogical University

\section{DYNAMICS OF THE TERMINOLOGY OF SPECIAL PEDAGOGY IN THE INFORMATIONAL EPOCH}

The author is studying the priorities of special education development in the context of the information society; formulates an understanding of the information of the XXI century challenges facing special education; to offer possible approaches in the education system to design the responses to these challenges.

The purpose of the article is to study the formation of terminology in the context of the development of domestic special pedagogy. Objectives of the article: to consider the evolution of views on the assistance to children with peculiarities of psychophysical development, to study the changes in the names of science, which studying the theory and practice of education and education of this category of persons. The article presents an analysis of the problem of transformation of institution of special education in Ukraine. It views the main factors regarding change of its content-related characteristics, orientation towards social integration and educational inclusion of children with special needs. The author analyzes the conceptual and categorical apparatus of special (defectological, correctional, inclusive) education in Ukraine, which is linked to implementation of inclusive practices for teaching children with special educational needs. The article presents comparative analysis of the terms "defectology", "correctional pedagogy" and "inclusive pedagogy". The author substantiates to denote the term "inclusive education" for marking the education for all children that study in a general educational institution.

The new model of disability must protect the rights of people with disabilities and become the basis for the unity of all people on Earth, regardless of their mental and physical characteristics.

Keywords: an information society; children with special needs; special education; defectology; correctional pedagogy; inclusive pedagogy.

П остановка проблеми. В еру становлення інформаційного суспільства знання набувають особливої соціальної цінності, у зв'язку з чим відбуваються кардинальні зміни в усіх сферах суспільного життя, у тому числі в освітній галузі. Важливо, щоб ці зміни не означали технократизацію освітньої сфери, адже має значення не інформаційна технологія сама по собі, якою б сучасною і прогресивною вона не була, а те, наскільки іiі використання слугуватиме досягненню освітніх цілей на гуманістичній основі. Практика свідчить, що залучення людей 3 особливостями психофізичного розвитку до сфери праці важливе як для них самих, так і для держави, оскільки поліпшується якість їхнього життя, платоспроможність, що стає особливо актуальним сьогодні внаслідок збільшення частки цієї категорії осіб. За даними ООН, приблизно 10\% жителів планети (понад 500 млн. осіб) мають вроджені чи набуті обмеження життєдіяльності. Лише якісна освіта здатна допомогти цим людям у питаннях самореалізації. Зміни статусу осіб з особливостями психофізичного розвитку в сучасному світі та освіти для них відображаються в мові, в тому числі термінології. Аналіз мовних змін у період, який науковцями називається інформаційним, мережевим, допомагає простежити характер і напрям змін суспільної свідомості.

Аналіз останніх досліджень і публікацій. Термінологію в еру становлення інформаційного 
суспільства вивчали дослідники - М. Амелін, інформаційного суспільства більшістю країн. Так, I. Віничук, М. Головань, В. Калашник, К. Мітяєв, “Декларації принципів побудови інформаційного I. Налєтова, М. Черпак та ін. Проблеми впорядкування понятійно-категоріального апарату висвітлювались у контексті впровадженням інклюзивних закладів [3, $61-64]$, в умовах соціальних трансформацій в інформаційну еру [4, $8-11 ; 5,5-9$ ], мовної соціалізації дітей 3 обмеженими можливостями здоров'я $[2,17-21$; 1, 40 - 43] та ін. Незважаючи на численність праць, ця проблематика вимагає докладного вивчення.

Мета статті - вивчити формування термінології в контексті розвитку вітчизняної спеціальної педагогіки, а завдання - розглянути зміну поглядів на допомогу дітям 3 особливостями психофізичного розвитку, проаналізувати зміни назв науки, що вивчала i вивчає теорію і практикунавчання і виховання цієї категорії осіб.

Виклад основного матеріалу дослідження. Динамічність термінології свідчить не лише про пошуки науковців у сфері надання допомоги, у тому числі освітньої, дітям з обмеженими можливостями здоров'я, а й про еволюцію поглядів у суспільстві на соціальний статус осіб зазначеної категорії, частина яких починає розглядатися як працездатний резерв. Сприяти належній освітній підготовці цих людей покликані не лише освіта, а й інформатизація суспільства загалом. На думку одного $з$ авторів концепції інформаційного суспільства Т. Стоуньєра, існують три основні способи, якими держава може збільшувати своє національне багатство: постійне накопичення капіталу, військові завоювання та територіальні прирощення, а також використання нової технології $[11,393]$. Завдяки високому рівню розвитку технології упостіндустріальній економіці останній із шляхів стає при створення нового багатства. При цьому на відміну від споживання матеріалів чи енергії, що веде до збільшення ентропії у Всесвіті, використання інформації призводить до протилежного ефекту-інформація збільшує знання людини, поліпшує організованість у навколишньому середовищі та зменшує ентропію $[11,404]$. Традиційні ресурси мають і вже окреслили свої рамки, а необмеженим у своїх можливостях залишається лише людський капітал. У наш час інформаційне суспільство лише частково сформувалося в країнах, до яких належать Сполучені Штати Америки, Японія, розвинені країни Європи: Фінляндія, Голландія, Німеччина, Великобританія. Світове визнання концепцій інформаційного суспільства призвело до планомірної реалізації стратегій побудови суспільства" зазначено наступне: 1) наука має центральну роль у розвитку інформаційного суспільства, багато 3 стандартних блоків інформаційного суспільства є результатом науково-технічних досягнень; 2) освіта, знання, інформація і комунікація є ядром людського прогресу, розвитку і добробуту; 3) інформаційнокомунікаційні технології мають величезний вплив на всі аспекти нашого життя, відкривають принципово нові можливості для досягнення більш високого рівня розвитку[7]. Не всі з цих принципів реалізовано в Україні, яка за індексом готовності до мережевого світу, розробленим Світовим економічним форумом, займала в 2015 році 71 місце серед 143 країн світу [6], проте у нас робиться чимало для того, щоб переваги інформаційного суспільства сприяли поліпшенню стану в галузі освіти, у тому числі спеціальної.

В історії науки галузь педагогічних знань, що вивчала сутність та закономірності освіти, навчання і виховання дітей з психічними і (або) фізичними порушеннями, мала різні назви спеціальна, лікувальна, реабілітаційна, допоміжна, ортопедична, віктимологічна педагогіка, соціальна педіатрія тощо [10]. Однією з перших була назва дефектологія (від лат. defectus

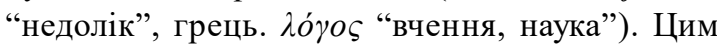
терміном позначали галузь знань, що вивчала особливості розвитку дітей з психічними та (або) фізичними вадами [9]. Наукове співтовариство відзначало “діагнозну” сутність терміна дефектологія, усвідомлюючи суперечність між етимологією терміна дефектологія і змістом наукового знання, яке він позначає. Ця суперечність негативно окреслилась після ратифікації Україною Конвенцій ООН “Про права інвалідів" та "Про права розумово відсталих". Суспільством була усвідомлена необхідність відмови від вживання термінів, які вказують на дефект. До таких термінів потрапили дефектологія, аномальні діти, аномальний розвиток, дефективні діти.

Динамічність термінології пов'язана зі зміною ставлення світової спільноти до людей 3 обмеженими можливостями. Ухвалення Загальної декларації прав людини (1948), Декларації прав дитини (1959), Декларації про права розумово відсталих осіб (1971), Декларації про права інвалідів (1975), Всесвітньої програми дій щодо інвалідів (1982), Саламанкська декларація про принципи, політику та практичну діяльність у сфері освіти осіб з особливими потребами (1994), 
Конвенція про права людей з інвалідністю (2006) та ін. демонструють гуманістичну спрямованість суспільної свідомості, визнання рівних прав усіх осіб на отримання освіти. У якості альтернатної назви 3 початку $1990-x$ pp. став використовуватися термін корекиійна педагогіка [9]. У сучасну педагогічну науку цей термін був упроваджений Г. Ф. Кумаріною в 1988 році, проте першу спробу розкрити його зміст здійснили на початку XX століття П.В. Кащенко і В.В. Мурашов у роботі “Лікувальна (корекційна) педагогіка” [10]. Заміна терміна дефектологія на термін корекційна педагогіка відбулася без обговорення у науковому співтоваристві, проте вже з 2007 року спеціальність дефектологія в Україні отримала назву корекиійна освіта, яка так само, як і попередній термін, залишалася в “діагнозному” термінологічному полі, оскільки об’єкт (дефект) замінили на дію (корекцію). Згодом приходить розуміння того, що ця галузь педагогіки займається не лише корекцією, але й іншими видами педагогічної допомоги адаптуванням до умов соціального життя; абілітацією в ранньому віці; реабілітацією (відновленням втрачених здібностей) педагогічними засобами; компенсацією відсутніх функцій; педагогічною допомогою батькам тощо. Термін корекційна педагогіка не відображає всю сутність педагогічної діяльності в сфері спеціальної освіти. Знаменно, що термін корекиійна педагогіка не отримав поширення серед зарубіжних фахівців для позначення даної галузі педагогіки, оскільки міжнародне вживання терміна корекційний відноситься ще й до роботи 3 девіантами. В англійській мові, зокрема, термін correction institution вживається зі значенням “корекційний (виправний) заклад, тобто в'язниця”. В нашій країні термін корекція також стосувався роботи з дітьми, які мають порушення поведінки, зокрема, в такому значенні його використовував В.П. Кащенко (див. його роботу “Педагогічна корекція").

У сучасній міжнародній педагогічній теорії і практиці загальноприйнятими $є$ терміни спеціальна педагогіка і спеціальна освіта: в англійській мові - Special education, у французькому - education speciale, в іспанській - pedagogia especial, cducacion especial, у німецькій - Sonderpadagogik. Англійський корінь назви special "особливий, індивідуальний" підкреслює особистісну орієнтованість цієї галузі педагогіки, її здатність вирішувати складні індивідуальні освітні проблеми конкретної людини. Термін спеціальна педагогіка не є неологізмом, він давно визнаний у науковому та професійному співтоваристві в Україні і за кордоном. Тривалий час він вживався як паралельна назва $з$ термінами дефектологія і корекиійна педагогіка. Цей термін адекватно відображає теорію і практику педагогічної допомоги особам з обмеженими можливостями здоров'я, у ньому відсутній зміст “діагнозу” по відношенню до дитини, термін не сприймається як ярлик, не принижує людську гідність, а тому термін спецііальна педагогіка здатний замінити дефектологію і є більш конкретним за змістом, ніж корекиійна педагогіка.

Термін спеціальна освіта до недавнього часу не міг вживатися як основна назва для позначення освіти осіб з особливостями психофізичного розвитку, для яких освіта у звичайних педагогічних умовах та за допомогою загальнопедагогічних методів і засобів $€$ ускладненою або неможливою, оскільки тривалий час цей термін разом з основною назвою середня спеціальна освіта використовувався для позначення професійної освіти середнього рівня, яку можна було отримати у технікумах, а також у деяких училищах (наприклад, медичному, педагогічному, ветеринарному, юридичному училищах). У наш час ці заклади отримали статус професійно-технічних. У Постанові Кабінету Міністрів України від 29 квітня 2015 р. № 266 у Перелік галузей знань і спеціальностей, за якими здійснюється підготовка здобувачів вищої освіти, термін спеціальна освіта використовується для позначення освіти осіб з відхиленнями у психічному чи фізичному розвитку i протиставлений професійній освіті.

Еволюція поглядів на систему освіти для осіб 3 особливостями психофізичного розвитку зумовила перегляд понятійно-категоріального апарату спеціальної педагогіки і відповідно термінології у їі межах. Певною мірою це пов'язано $з$ виникненням нового різновиду навчальних закладів на стику загальної та спеціальної освіти, які отримали назву інклюзивних. Термін інклюзія перекладається 3 англійської мови як включення або приєднання. Традиційно поняття інклюзивної освіти обмежувалось визначеннями, які стосувалися переважно реалізації права на надання освіти та соціальну інтеграцію осіб з особливостями психофізичного розвитку. Проте у наш час ця концепція зазнала змін, згідно з якими інклюзія поширюється на всіх дітей, які повинні мати умови та можливості в сфері освіти, незалежно від їх культурного, економічного та соціального стану, а також психофізичних особливостей [3, 61 - 64]. Дійсно, інклюзивна освіта повинна надавати 
можливість кожній дитині, незважаючи на наявні фізичні, інтелектуальні, соціальні, емоційні, мовні та інші особливості, бути включеною до спільного процесу навчання та виховання для того, щоб у майбутньому ці діти могли стати рівноправними членами суспільства [12].

В еру становлення інформаційного суспільства актуалізується повага до людського розмаїття, встановлення принципів солідарності та безпеки, що забезпечує захист та повне інтегрування у соціум усіх верств населення, у тому числі осіб 3 обмеженими можливостями здоров'я. Використання інформаційних технологій в закладах спеціальної освіти, розвиток дистанційної освіти на основі цих технологій сприяє реалізації цього завдання. Становлення інформаційного суспільства стосується не лише освіти, а й інших сфер, включаючи суспільне виробництво, сферу праці та зайнятості. До основних проявів цього становлення на ринку праці та зайнятості можна віднести зростання потреби у науково-технічних кадрах і фахівців високої кваліфікації і, відповідно, зниження потреби у некваліфікованій робочій силі, а це означає, що фізичне порушення людини при її інтелектуальній спроможності у наш час не завжди може сприйматися негативно при працевлаштуванні, зокрема, коли йдеться про працевлаштування фахівців усфері інформаційнокомп'ютерних і телекомунікаційних технологій. Робота 3 використанням інтернету є новою формою зайнятості та використання трудових ресурсів і виконується в місцях, віддалених від центрального офісу. Поширення електронного надомництва дозволяє забезпечити наближення роботи до людини, а не людини до роботи [8]. Такий різновид організації праці створює передумови для включення осіб з особливостями психофізичного розвитку в трудову діяльність та повнішому використанню їхніх здібностей. Звісно, окреслене майбутнє для цієї категорії осіб слід забезпечити уже сьогодні в закладах спеціальної освіти.

Висновки. Дослідження понятійно-категоріального апарату та термінології у межах спеціальної освіти відображає зміни у поглядах на статус осіб 3 особливостями психофізичного розвитку в сучасному світі. Ера становлення інформаційного суспільства, що базується на сучасних комп'ютерних і комунікаційних технологіях, уже в наш час створює умови для реалізації можливостей для розвитку людини, її освіти як творчої особистості. Тлумачення інформаційного суспільства як втілення духу технократизму, а інформатизації освіти як прояву технократичного мислення уявляється нами як те, що не відповідає реальності. Інформатизація суспільного життя загалом сприяє його гуманізації.

\section{ЛІТЕРАТУРА}

1. Ашиток Н. І. Мовна картина світуу філософськоосвітньому аспекті. Вісник Національного авіаційного університету. Серія: Культурологія: Зб. наук. пр. №2 (12). 2010 . С.40 - 43.

2. Ашиток Н.І. Мовна соціалізація дітей 3 особливостями психофізичного розвиткув умовах інформаційного суспільства. Молодь і ринок. № 4(111). 2014. С.17 - 21 .

3. Борохвіна Т.Г. Понятійно-категоріальний апарат інклюзивної освіти. Сучасна педагогіка: теорія, методика, практика. Чернігів, 2018. С. 61 -64 .

4. Дротянко Л.Г. Соціальні трансформації мовленнєвої культури в інформаційну еру. Вісник Національного авіаційного університету. Сер. : Філософія. Культурологія. 2014. № 1. С. 8 - 11 .

5. Дротянко Л.Г. Трансформація комунікативної функції мови в добу інформатизації. Вісник Національного авіаційного університету. Сер. : Філософія. Культурологія. 2012. № 2. С. 5 - 9.

6. Всемирный экономический форум: индекс сетевой готовности 2015 года. Режим доступу: https://gtmarket.ru/news/2015/04/17/7128

7. Декларация принципов "Построение информационного общества - глобальная задача в новом тысячелетии". - Режим доступу: http:// www.gov.karelia.ru/Leader/Inform/Egov/tunis.html

8. Зайцева О.Б. Глобализация и ее влияние на труд лиц с ограниченной трудоспособностью. URL: http://www.rae.ru/use/?section =content\&op =show article\&article $\mathrm{id}=7778496$

9. Постоева В.А., Шелехов И.Л. Коррекционная педагогика с основами специальной психологии. Томск, 2008. 292 с.

10. Синьов В. М. Методологія та теорія досліджень в галузі дефектології. URL: http:// fkspp.at.ua/Bibl/15.pdf

11. Стоуньер Т. Информационное богатство: профиль постиндустриальной экономики. Новая технократическая волна на Западе. Москва, 1986. С. $392-409$.

12. Сунцова А.С. Теории и технологии инклюзивного образования: учеб. пособ. Ижевск, 2013. $110 \mathrm{c}$.

\section{REFERENCES}

1.Ashytok, N. I.(2010). Movna kartyna svitu u filosofsko-osvitnomu aspekti [Language picture of the world in the philosophical and educational aspect]. Bulletin of the National Aviation University. Series: Culturology, Vol. 2 (12), pp. 40 - 43. [in Ukrainian]. 
2.Ashytok, N. I. (2014). Movna sotsializatsiia ditei z osoblyvostiamy psykhofizychnoho rozvytku v umovakh informatsiinoho suspilstva [Language socialization of children with peculiarities of psychophysical development in the conditions of information society]. Youth and market,Vol. 4(111), pp. 17 - 21. [in Ukrainian].

3.Borokhvina, T. H. (2018). Poniatiinokatehorialnyi aparat inkliuzyvnoi osvity [Conceptuallycategorical apparatus of inclusive education]. Modern Pedagogy: Theory, Methodology, Practice, pp. 61 - 64. [in Ukrainian].

4. Drotianko, L. H. (2014). Sotsialni transformatsii movlennievoi kultury $\mathrm{v}$ informatsiinu eru [Social transformations of speech culture into the information age]. Bulletin of the National Aviation University. Series: Philosophy. Culturology, Vol. 1, pp. 8-11. [in Ukrainian].

5. Drotianko, L. H. (2012). Transformatsiia komunikatyvnoi funktsii movy v dobu informatyzatsii [Transformation of the communicative function of language in the era of informatization]. Bulletin of the National Aviation University. Series: Philosophy. Culturology, Vol. 2, pp. 5 - 9. [in Ukrainian].

6. Vsemirnyiy ekonomicheskiy forum: indeks setevoy gotovnosti 2015 goda, 2015. [World Economic Forum: 2015 Readiness Index]. Available at: https:// gtmarket.ru/news/2015/04/17/7128 [in Russian].

7. Deklaratsiya printsipov "Postroenie informatsionnogo obschestva - globalnaya zadacha v novom tyisyacheletii" [Declaration of Principles "Building an Information Society - A Global Challenge in the New Millennium"]. Available at: http:// www.gov.karelia.ru/Leader/Inform/Egov/ tunis.html[in Russian].

8. Zaytsev, O. B. Globalizatsiya i ee vliyanie na trud lits s ogranichennoy trudosposobnostyu [Globalization and its impact on the work of persons with disabilities]. Available at: http://www.rae.ru/use/ ?section $=$ content\&op $=$ show article\&article $\mathrm{id}=7778496$ [in Russian].

9. Synov, V.M. Metodolohiia ta teoriia doslidzhen $\mathrm{v}$ haluzi defektolohii [Methodology and theory of research in the field of defectology]. Available at: http://fkspp.at.ua/Bibl/15.pdf [in Ukrainian].

10. Postoeva, V.A. \& Shelehov, I. L. (2008). Correktsionnaya pedagogika s osnovami spetsialnoy psihologii [Correctional pedagogy with the basics of special psychology]. 292 p. [in Russian].

11.Stonier, T. (1986). Informatsionnoe bogatstvo: profil postindustrialnoy ekonomiki [Information wealth: the profile of the post-industrial economy]. New technocratic wave in the West. pp. $392-409$. [in Russian].

12. Suntsova, A. S. (2013). Teorii i tehnologii inklyuzivnogo obrazovaniya [Theories and technologies of inclusive education]. Izhevsk, $110 \mathrm{p}$. [in Russian].

Стаття надійшла до редакції 15.03.2019

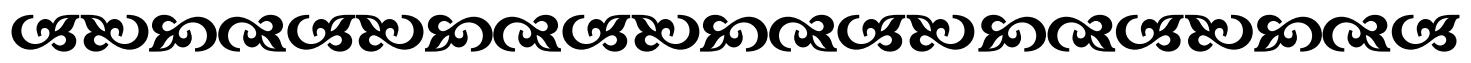

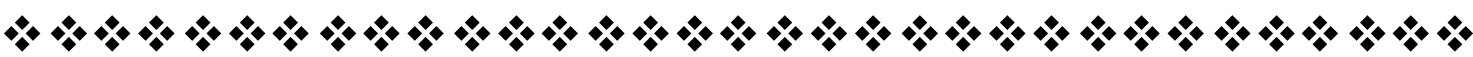

"Mema - uе шляху уасі".

\author{
Kapл Ясперс \\ німецький ббілособ
}

"Хто хоче зрушити світ, нехай зрушить себе!"

Соқрат

давнъогреиький білособ

“Фля того, щоб прийти до справжнъого знання, треба спочатку відчути сумніви”.

Apicmoтель

давньогреиький біліособ

"भіщо не буває рано, нішо не буває пізно. Все буває вчасно".

Конфучиій

давньоқитайський ббілособб

\section{$\% \%$

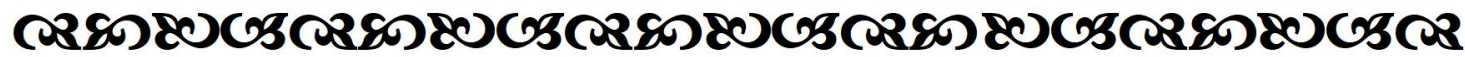

